\title{
Review and Prospect of the research on Tourism Education in China
}

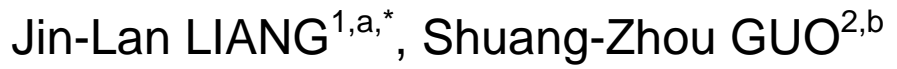 \\ ${ }^{1}$ Department of Travel Ningbo City College of Vocational Technology, Zhejiang Ningbo China \\ ${ }^{2}$ Ningbo City College of Vocational Technology, Zhejiang Ningbo China \\ apkuguosz@163.com, bkingsz@126.com
}

Keywords: Tourism education, Tourism education research, Statistical analysis.

\begin{abstract}
By China CNKI, literature retrieval of tourism education during the period of 1979-2016 published, from the development of tourism education and tourism talents cultivation, regional tourism education, tourism specialty teaching mode, teaching content and course of tourism and foreign tourism education aspects analyzed and summarized the research status of Chinese tourism education, think to explore the future of theoretical depth and research Chinese tourism education tourism research discipline construction and tourism education content development will further strengthen.
\end{abstract}

\section{Introduction}

With the development of tourism, the scale of tourism education in China has been expanding. A multi-level education system has been formed. From 2001 to 2005, the number of high and medium tourism schools increased by 184, and tourism institutions all over the provinces, autonomous regions and municipalities directly under the central government. By 2005, there were 1336 high schools and secondary schools, with the number of students being over 560 thousand[1]. With the development of tourism education, the research on tourism education has also been carried out gradually. However, whether it is compared with foreign countries or from the needs of the practice of tourism education, the study of tourism education in China is obviously lagging behind. Therefore, it is an important theoretical topic to review and summarize the current situation of the development of domestic tourism education research and to clarify the direction of future efforts.

\section{Source of Literature}

In this paper, using the Internet to Chinese Journal Full-text Database as the information source of statistics, select the "tourism education", "tourism talents" as key words, search all the 1979 -2007 year in October for nearly 30 years, 812 articles, of which 12 pieces of repeated, this paper is mainly analyzed 800 articles, to by the quantitative analysis and qualitative study of domestic tourism education research status. The study of domestic tourism education is almost synchronized with the development of tourism education. From the number of published papers in the past years, before 1994, the domestic research

Table1. The number of documents on "tourism education" published over the years

\begin{tabular}{|l|l|l|l|l|l|l|l|l|l|l|l|l|}
\hline Time & 2016 & 2015 & 2013 & 2012 & 2011 & 2010 & 2009 & 2008 & 2007 & 2006 & 2005 & 2004 \\
\hline $\begin{array}{l}\text { Number } \\
\text { of articles }\end{array}$ & 282 & 274 & 246 & 229 & 204 & 187 & 162 & 156 & 101 & 134 & 109 & 98 \\
\hline Time & 2003 & 2002 & 2001 & 2000 & 1999 & 1998 & 1997 & 1996 & 1995 & 1994 & 1993 & 1992 \\
\hline $\begin{array}{l}\text { Number } \\
\text { of articles }\end{array}$ & 76 & 37 & 33 & 32 & 45 & 34 & 24 & 28 & 12 & 8 & 2 & 4 \\
\hline
\end{tabular}

Study on tourism education is still in the exploratory stage, the quantity is very few, and belongs to the study of the true meaning of the almost blank; in 1995 after entering the initial stage of development, from the beginning, number of papers of domestic tourism education research increased gradually; on 2013 the tourism education field has taken a leap forward development, in 
2005 the number of papers for the first time exceeded Article 100 (specific data see Table 1). From the statistics of the published literature, the domestic concern about tourism education is increasing year by year.

A review of the research

From the research content of published literature, domestic tourism education research mainly focuses on tourism education development, personnel training, regional tourism education, professional teaching mode, curriculum and teaching content and overseas tourism education, etc. (see Table 2). This article reviews and reviews the 6 main aspects of the main research.

Table 2. published the contents of the literature on "tourism education" in calendar year

\begin{tabular}{|l|l|l|l|l|l|}
\hline Ordinal & research contents & $\begin{array}{l}\text { Number } \\
\text { of articles }\end{array}$ & Ordinal & research contents & $\begin{array}{l}\text { Number } \\
\text { of articles }\end{array}$ \\
\hline 1. & Development Research & 537 & 7. & $\begin{array}{l}\text { Function of Tourism } \\
\text { Education }\end{array}$ & 135 \\
\hline 2. & personnel training & 324 & 8. & Ecotourism Education & 75 \\
\hline 3. & $\begin{array}{l}\text { Regional Tourism } \\
\text { Education }\end{array}$ & 317 & 9. & $\begin{array}{l}\text { Introduction of colleges } \\
\text { and figures }\end{array}$ & 67 \\
\hline 4. & $\begin{array}{l}\text { Professional teaching } \\
\text { model }\end{array}$ & 297 & 10. & $\begin{array}{l}\text { Research on running a } \\
\text { school }\end{array}$ & 36 \\
\hline 5. & $\begin{array}{l}\text { Curriculum and teaching } \\
\text { content }\end{array}$ & 207 & 11. & $\begin{array}{l}\text { Research on Teachers' } \\
\text { team }\end{array}$ & 32 \\
\hline 6. & Foreign tourism education & 144 & 12. & Other & 342 \\
\hline
\end{tabular}

\section{Research on the Development of Tourism Education}

The development of tourism education research for tourism education research in the largest proportion, mainly on the problems and Countermeasures of tourism education in the article as the main analysis of the tourism education present situation, nature, characteristics, external environment, emphasis on the coordinated development of tourism industry and tourism education, and according to the characteristics of the times, put forward thinking and development trend strategy.

The scholars first reviewed the development course of China's tourism education and discussed the corresponding development trend. Hanjun Tao reviews the stage of development of tourism education in China from the last century since 50s, will be divided into initial stage, development stage and standard stage, and pointed out that China's tourism education has formed a relatively complete system of positive structure, standardization direction development [2]. Ding Li and other national tourism demand has been saturated, and the quality of tourism education is not high. It is pointed out that tourism education in China should transform from simple quantity expansion to quality pursuit, from extensive to intensive development [3]. Zhijiang Liu observed the development course of tourism education in China for more than 20 years, analyzed the application characteristics of tourism education, thought that tourism education should be compatible with the development of tourism industry, and emphasized the important role of tourism basic theory research [4].

Some scholars on China's higher tourism education of Lihua Tang, through analyzing the characteristics of occupation education in educational objectives, educational content, educational methods, educational media education of four elements, that tourism higher education is a professional education with distinctive characteristics of occupation, should be oriented and serve the tourism industry [5]. Mountains Qinling South pointed out that tourism higher education should deal well with the relationship between vocational education and professional education. It can clearly divide the boundaries of higher vocational education through institutional arrangement within tourism institutions, so as to avoid the confusion of tourism research and the tourism higher education [6].

There are researches on the existing problems in China's tourism education and countermeasures should be taken, such as Huimin Gu through the investigation of 200 tourism colleges nationwide, 
China pointed out that tourism education in teachers, students' practical experience and the degree of internationalization should be further improved to [7]. Longjiang Zhi pointed out that Chinese tourism higher education is faced with "education expansion", "talent scarcity" and "employment pressure", "brain drain" a series of sharp contradictions and conflicts, and its root is the lack of basic discipline, key to get rid of the dilemma is the basic problem of clear discipline, discipline construction of core knowledge system [8]. Bihu Wu and so on, on the basis of a comprehensive statistical analysis of the various aspects of tourism in China, pointed out the gap between China and foreign countries, and put forward that we should further strengthen in tourism discipline construction [9], curriculum reform, and textbook compilation and so on.

Although scholars have studied the development of tourism education in China more deeply, the extensive growth of tourism education in China, the disconnection between education and practice, the serious loss of tourism talents and the rising employment pressure are also undeniable facts. Therefore, how to better expand the development of tourism education according to the practice of tourism education in China is a link that the academic circle must pay attention to.

\section{Research on the Training of Tourism Talents}

The key of tourism competition lies in the competition of tourist talents. Therefore, the research on the training of tourism talents has attracted much attention of scholars. Statistics show that talent training is mainly based on personnel training mode, current situation and countermeasures, including quality training, problems in training process and training of special talents.

Guoqing Wu and Xinliang Ye, from the phenomenon of dislocation of supply and demand of tourism talent market of that occupation orientation should be one of the direction of development of tourism higher education, put emphasis on linking theory with practice, to cultivate students to have a relatively wide range of professional knowledge and solid post skills talents [10]. Based on the analysis of the problems existing in the training of tourism professionals, Jiyuan Huang put forward that talents training should adapt to the development level of tourism industry in twenty-first Century, promote quality education and integrate with international [11]. Wang combined with the Research Institute of Ningbo College of Vocational Technology travel personnel training mode as an example, points out that as a professional education with distinct occupation characteristics, tourism higher education should be employment oriented, to cultivate high quality talents of tourism needs, [12] realize the virtuous cycle "to learn about production to production, production support Research of mutual promotion" to research the. Peiling Ji, the army through social investigation and empirical data comparison, analysis of current situation of tourism industry in recent years, the present situation of human resources and training colleges, pointed out that the total balance and monomer imbalance of talent resource conflicts, we should re adjust the personnel training mode according to the structure design of [13] culture industry development level of personalized. Peiyin Zhang summarized the training mode and practice education method of tourism and Cuisine College of Harbin University of Commerce, and set up a set of platform plus module training mode [14] for tourism higher education, integrating theory and practice.

From the perspective of vocational education, the training of tourism talents in China has been done well in the combination of theory and practice. However, in the undergraduate, even master or doctor level of talent training, whether it is theoretical research or educational practice, the current situation is not optimistic. Therefore, the research on high level training of tourism talents should be the focus of this research.

\section{Study on the Teaching Mode of Tourism Specialty}

The research on the teaching mode of tourism majors mainly discusses the teaching methods, contents, means and problems in the teaching, and puts forward the corresponding reform measures.

Ma Yong and others put forward a three in one tourism education optimization mode based on teaching, skills training and scientific research oriented development, and analyzed the mode. Xuecheng Liang and others, aiming at the shortcomings of our traditional educational concepts and teaching modes, embark from the theory and practice of tourism education, put forward a tourism experimental teaching mode that is compatible with modern educational technology, and made 
preliminary design and arrangement. Zhang Peiyin and others hold that the innovative teaching system of tourism higher education is composed of 3 parts: knowledge cultivation, practical ability training and innovative education quality management. The teaching mode of "production, learning and research" is an innovative practice of tourism higher education. Hu Shanfeng uses the modern marketing idea, to reform the traditional teaching mode of tourism, based on the "quotas" idea of establishing a new teaching mode. Tang Yuegong discussed the construction and path of the tourism education mode of Applied University, pointed out the existing problems in our education mode, and put forward two teaching modes: order form and engineering alternation. Chen Zhifu proposed to build a new development mode of Higher Vocational Education of tourism, which is suitable for the development of modern tourism. Skill education is the core. Industrialization is the general plan of development. People oriented is the new concept of education, and internationalization is the trend of development. Zhu Yaduo put forward the innovation education development model of "theory + practice", relying on Industry Association, strengthening professional practice ability and taking the road of integration of production, learning and research.

The author thinks that the research on the teaching mode of tourism major may need to be considered from the level, specification and target of talent training. Different professional level of talent training, the professional teaching mode should be different. For example, occupation training talent level, may need to practice exercises as a professional teaching mode plays the leading role; cultivation of masters and doctors, may need to the theory and methods of teaching mode dominated; undergraduate education level, professional teaching mode selection, may according to the specific needs of the University and the training goal set.

\section{Study on Tourism Curriculum and Teaching Content}

The study of curriculum and teaching content takes curriculum as the main body, and analyzes its characteristics, problems and its connection with tourism management activities. The curriculum system is a whole. The organic combination of courses of different nature and content shows different values and functions, determines the training specifications and knowledge structure of talents. The study of the curriculum system is divided into two types: "series" and "module".

Energy-saving from the higher education of tourism major is applied composite professional perspective, believe that the curriculum should break through the traditional higher education curriculum system construction mode, establish consists of main courses, skills courses, Knowledge Series Curriculum system. Ning Du thought that we should reform the traditional curriculum system based on knowledge education, and build a curriculum system based on general education curriculum, subject education curriculum, professional education curriculum and professional direction education curriculum. Lin Gang, Jing Xiuyan from the professional tourism management as a management science perspective, including the proposed management professional common basic curriculum series, tourism course series, tourism management curriculum and modern management talent education series curriculum form.

Chunxiao Xu through the analysis of the current characteristics of the course system, thought the curriculum system of Tourism Management Undergraduates exist under layer structure, skewness, utilitarian and obvious characteristics of assembling and other issues, the process and professional activity curriculum is divided into professional basic courses, professional theory courses, professional application class four modules. From the organic combination of quality education and professional education, Xizhou Tian set up a curriculum system consisting of three modules: quality education curriculum group, professional basic education curriculum group and professional development education curriculum group. Zhao Peng thought that we should strengthen the flexibility of curriculum system, open up the basic teaching of various specialties, and build specialized courses with modules, and put forward a modular curriculum structure consisting of basic curriculum modules, professional curriculum modules and expanded curriculum modules.

Although scholars have done many researches on the curriculum and teaching content of tourism management, however, due to the immaturity of tourism discipline, the curriculum and teaching content setting (including teaching materials) of domestic tourism management specialty is still not 
satisfactory. The root of the problem is probably due to the weakness of the research on the basic theory of tourism, which has not yet formed the structure of the whole subject. In this context, it is obviously futile to build a complete curriculum system and a solid content of teaching. Therefore, it is the real way to deepen the research on the basic theory of tourism discipline.

\section{Research Prospect}

Scholars' research on tourism education has greatly promoted the development of tourism education, made tourism education in China become more standardized and the tourism education system has been improving. The literature retrieved in this article may not cover all the literature of the tourism education research, and may have some omissions. However, this paper clearly covers published on "Tourism Tribune", "Journal of Guilin Institute of Tourism and other domestic tourism research focus of the journal literature, therefore, the result is very strong representative. Based on the literature on Tourism Education in China, combined with the practice of tourism education in China, we believe that the future research of tourism education in China will be further expanded in the following aspects.

\section{Further Enhancement of the Theoretical Depth of Tourism Education Research}

From the perspective of the contents, the research of tourism education in China involves many fields, such as tourism education development, personnel training, regional tourism education, professional teaching mode, curriculum and teaching content, and so on. However, some articles are far from enough. There are a large proportion of articles about the current situation, existing problems and Countermeasures of tourism education. However, there is no innovation and stereotyped content, which makes tourism education repeat more phenomena at a low level. At present, the empirical research on the relationship between basic theory and tourism development, the evaluation of talent cultivation quality and the comparative analysis of tourism education abroad should be further strengthened. The study of tourism education should also absorb the new achievements in the field of education research from the research methods, and strengthen the depth of theoretical research with the help of modern educational research methods.

\section{Further Deepening the Research on the Construction of Tourism Discipline}

Since 1995, the amount of literature on tourism education has begun to increase year by year, and has maintained a relatively high growth rate every year, and is gradually becoming a relatively independent research field. However, the development and construction of tourism discipline of tourism education is inseparable, tourism education as an ongoing social practice requires a certain discipline system guidance, according to the mature subject system of tourism by the study, setting and adjustment of tourism specialty and curriculum, training, training of tourism professionals. Although many scholars of the system and the nature of tourism science have made a lot of research on 6,47,4, but because of the lack of theoretical system of tourism support, China's tourism science is not stable, hindered the further development of the tourism industry and tourism education, deepening the construction of tourism discipline become critical to the development of tourism education.

\section{The Exploration of the Connotation Development Road of Tourism Education will be Further Discussed}

To strengthen tourism education in China, with the development of tourism industry, after nearly 30 years of efforts, it has formed a multi-channel, multi-directional and multi-level tourism education pattern. However, there are still some problems, such as inadequate teachers, unreasonable curriculum, simple teaching equipment, and nonstandard teaching materials. The reason for China's tourism education mainly adopts the development mode of "extensive" expansion, internal education quality and the expansion of scale is not synchronized, this development model has practical development of tourism education in our country, but with the transformation of the economic system, gradually adapt to the development of tourism education, leading to the quality of education in 
wandering low level, teaching content and professional practice, students employment difficulties and a series of contradictions and conflicts. Changing the "extension" for quality oriented "connotative" development mode, integrating existing educational resources and improving the quality of teaching and research is the focus of further discussion in tourism education.

\section{Reference}

[1] National Tourism Bureau.2015 National Tourism University basic situation [EB/OL]. http://www.cnta.com/news.detail/newsshow.asp? Id=A20066231131284148805.

[2] Han Tao. On the stage of the development of tourism education in our understanding of the [J]. Tourism Tribune, 2016:6-9. (In Chinese)

[3] Ding Li, Dongmei He, Xin Ye. On China's tourism education growth pattern of [J]. Tourism Tribune, 2016:15-18. (In Chinese)

[4] Zhijiang Liu. Adaptive problems concerning the development of tourism education and tourism [J]. Journal, 2014:19-21. (In Chinese)

[5] Lihua Tang. The basic characteristics of occupation education of tourism higher education [J]. Tourism Tribune, 2016:80-86. (In Chinese)

[6] south of Qinling Mountains. See higher tourism education from the perspective of [J]. tourism tourism, 2015:19-22. (In Chinese)

[7] Valley Vivian, et al. Research on current situation and Countermeasure of tourism tourism education Chinese [J]. 2016:22-29.

[8] Longjiang Zhi. China tourism higher education offbeat interpretation of [J]. Tourism Tribune, 2016:16-22. (In Chinese)

[9] Bihu $\mathrm{Wu}$, Xiaoxiao Li. Chinese tourism education development report [J]. Tourism Tribune, 2015:9-15. (In Chinese)

[10] Guoqing Wu, Xinliang leaves. The cultivation of tourism talents and higher education of tourism occupation development [J]. Tourism Tribune, 2014:15-18. (In Chinese)

[11] Jiyuan Huang. Discussion on [J]. Tourism culture reform mode and teaching content of tourism talents in vocational colleges, 2015:99-102.

[12] Jiang Lin Zhou. Set up a platform for training tourism talents with the combination of production, learning and research [J]. Guilin Institute of Tourism journal, 2016, (2): 54-58. (In Chinese)

[13] Peiling Ji, the army. [J]. Journal of Travel Research on the training mode of tourism resources based on the demand of talent education stratification, 2015:57-61. (In Chinese)

[14] Peiyin Zhang, Zhao Yang, Shi long. Thinking and Practice on education mode and method of tourist talents of [J]. Tourism Tribune, 2016:113-116. (In Chinese) 